\title{
Performance of Regional Staffing Agency Services in order to Increase the Rank of Civil Servants of Murung Raya Regency of Central Kalimantan
}

\author{
Yanson Dion \\ Study Program in Public Administration, Faculty of Social and Political Sciences, Lambung Mangkurat \\ University, Banjarmasin City, South Kalimantan, Indonesia
}

\begin{tabular}{l} 
Article Info \\
\hline Article history: \\
Received Oct 12, 2021 \\
Revised Dec 10, 2021 \\
Accepted Dec 25, 2021 \\
\hline
\end{tabular}

Keywords:

Service Performance Service Performance Factors Public Service Personnel

\begin{abstract}
This research aims to describe and analyze the performance of services and what factors affect the service performance of the Regional Staffing Agency in the framework of the promotion of Civil Servants of the Regional Staffing Agency in the framework of the promotion of Civil Servants in Murung Raya Regency. The approach taken in this study is a qualitative approach with the instrument is an interview. Measured, as well as documents that support the author in using informant data in this study amounted to 15 people consisting of Employees at the Regional Staffing Agency of Murung Raya Regency.

The results of the Regional Staffing Agency's service performance research in terms of promotions seen from productivity, service quality, responsiveness, responsibilities and accountability in Murung Raya Regency have been good. That is, from the receipt of files, file verification, management to $\mathrm{BKN}$ Regional Kalimantan to the issuance of the promotion decree is basically in accordance with the regulations, in accordance with the vision of BKD's mission and provides good satisfaction to the community of service users (PNS) of Murung Raya regency. The performance of promotion services in BKD Murung Raya which is an obstacle factor such as changing rules about the technical requirements of promotion, there are still some civil servants who are late to submit their files or files submitted incomplete and the distance between BKD and BKN Regional Banjarbaru so that the enactment is scheduled earlier or faster.
\end{abstract}

This is an open access article under the CC BY-SA license.

\section{Corresponding Author:}

Yonson Dion

Study Program in Administration Public,

Faculty of Social and Political Sciences, Lambung Mangkurat University, Banjarmasin City

Jl. Brigadier General H. Hasan Basry. Tangi Wood

Email: yansonoargopuro@gmail.com

\section{INTRODUCTION}

Noting the above, it is seen that the importance of understanding transformational leadership styles and work commitments in an effort to improve the performance of staffers at the Regional Secretariat of Murung Raya Regency. This is considering that the Regional Secretariat of Murung Raya Regency is one of the Large Regional Device Organization Units within the scope of a regency that will determine the success of the implementation of government in accordance with the vision and mission of Murung Raya Regency [1].

The birth of Law No. 32 of 2004 which was revised into Law No. 23 of 2014 on Local Government, has very broad implications for the implementation of civil servant management in the area. Regions are authorized to carry out appointments, removals, dismissals, pension determinations, salaries, benefits, and 
welfare, as well as education and training in accordance with the needs and capabilities of the region stipulated by local regulations, based on laws and regulations. Then based on law No. 43 of 1999 on Staffing Points that have been changed to Law No. 5 of 2014 on the State Civil Apparatus, that staffing affairs that were previously the full authority of the central government have now been transferred to the authority of the local government whose arrangements are guided by rational policies set by the central government[2][3][4].

Regional staffing is a system or procedure stipulated in the laws and regulations including: planning, requirements, appointment, placement, education and training, payroll, dismissal, retirement, coaching, standing, rights, obligations, responsibilities, prohibitions, sanctions, and awards are a subsystem of the national staffing system. Thus, regional staffing is a unified bureaucratic network in national staffing [5]. In this case, the Regional Staffing Agency (BKD) is a local government organization that has a large role to manage staffing management and services to civil servants in the area related to staffing, both provincial BKD and BKD district / city. One of them is BKD Murung Raya Regency of Central Kalimantan Province.

The legal aspect of the existence of the Regional Staffing Agency of Murung Raya Regency is contained in the Regional Regulation of Murung Raya Regency Number: 06 of 2015 concerning the Establishment of Organization and Working Procedures of inspectorates, agencies, regional development planning and regional technical institutions of Murung Raya regency. In the Regulation mentioned that the Position and Basic Duties and Functions of the Regional Staffing Agency of Murung Raya Regency are supporting elements of the Regional Government in the field of implementation of regional staffing management. Where, the Regional Staffing Agency of Murung Raya Regency is led by a head of the Agency who is under and responsible to the Regional Head through the Regional Secretary of Murung Raya Regency to carry out these tasks. In this case, although BKD Murung Raya Regency is only an element of supporting regional staffing management, it remains the focus of staffing management managers, which of course BKD is also required to provide the best performance in the framework of service to regional civil servants, especially regional civil servants of Murung Raya Regency [3][4].

In accordance with the Regional Regulation of Murung Raya Regency Number: 17 of 2016 concerning the Establishment and Working Procedures of agencies in the environment of the Regional Government of Murung Raya Regency. The position of the Regional Staffing Agency has its main duties and functions as a supporting element of the Government in the field of Civil Servant management in this case concerning the construction of staffing administration, procurement and employee mutation, employee welfare as well as the construction of discipline and dismissal and career development of employees, including regarding the promotion of employees. Rank is a position that indicates the level of a civil servant based on his position in a series of staffing arrangements and used as a study basis. Promotion is an award given for the work performance and service of civil servants to the state. Promotion is carried out based on the regular promotion system and the preferred promotion system. The proposed period of promotion of civil servants is twice a year, namely April and October [4].

Based on the initial survey conducted in June 2018, BKD data of Murung Raya Regency the number of civil servants in Murung Raya Regency until June 2018 amounted to 3,850 people. Then it was increased again with the addition received for regional CPNS admission in October 2018 as many as 90 people for the CPNS formation which consisted of 32 teachers, 18 health workers and 40 technical personnel. That is, BKD Murung Raya always serves the interests of civil servants in terms of regional staffing interests, including regarding the promotion of 3,940 civil servants.

Managing promotions as part of BKD's work, demands good performance. This demand requires a serious effort to make it happen because the current performance of the government bureaucracy is suspected to still not show high performance. This is marked one of them is the low quality of service provided by bureaucrats to the community and this is also often blamed as one of the factors that cause the decline of this country [6]. This concern applies also to BKD Murung Raya Regency in order to serve regional civil servants.

Improving the performance of services to the community is not an easy thing, because it is an open secret that there is a lot of public disappointment with the services provided by the government so far. The utilization program of the state apparatus did not succeed in presenting an efficient and vibrant bureaucratic display of serving thecommunity[13][14][15]. Kesulitan and obstacles that are often complained about in receiving services from the apparatus in general such as procedures and procedures of service that are lacking / unclear, burdensome or often variable requirements, service is not on time and time of service / settlement is too long, service mechanisms that are often convoluted, too bureaucratic and uncertain service costs[21][22]

In the management activities of the promotion of Regional Civil Servants in the Regional Staffing Agency murung Raya the phenomena that show challenges for BKD that may often be complained about in receiving services from the apparatus as mentioned above, which relate to performance or indications of dissatisfaction with the quality of management of the promotion include the following:

1. Management time can be on time and can also be late.

$\overline{\text { Performance of Regional Staffing Agency Services in order to Increase the Rank of Civil Servants of Murung }}$ Raya Regency of Central Kalimantan 
The management of the promotion each year is divided into two periods, namely April 1st and October 1 st. The management of the promotion can be timely, it can be timeless. Timely means that the management is right in each period of his proposal, for example if a Civil Servant is proposed to increase his rank on April 1st, then the employee should receive a decree of promotion before April 1st of the year concerned. Not on time means that the management of the promotion is completed beyond the period of his proposal, so that the decree of the promotion itself is received by the employee concerned after the date of the promotion period. This results in delays in the receipt of salaries in the new rank and class of space, thus financially harming the employee concerned,

2. Allocation of costs / operating budget of promotion management

The allocation of funds for the management of promotions from the Murung Raya Regency APBD determines the balanced performance with the growing task load. The Regional Staffing Agency of Murung Raya Regency every year requires a budget for promotion management activities,

3. Possible administrative errors in the management of promotions

The possibility of errors / administrative deficiencies in the management of promotions causes many requests for correction of the decree of promotion every period, both from the proposing agency and directly from the civil servant concerned. Mismanagement of this promotion such as name typing errors, Employee Master Number (NIP), class / space, working period, work location, basic salary, position, promotion period and so on,

4. Image of a promotion as a "right" not an "award".

Some Regional Civil Servants in the ranks of the Regional Government in Murung Raya still consider that the promotion as an administrative routine that becomes the "right" of civil servants, so there is an image that every civil servant will definitely get a promotion as his right without ever caring about the duty of his obligations have been carried out properly or not. They consider the promotion is not an important thing that requires special attention, because the assumption is that as long as the employee has fulfilled the specified working period, then automatically a Civil Servant can rise through the ranks. This situation fosters a kind of conclusion that it is also their right to make a claim or complain if they feel they are not getting the service of promotion properly (as expected). The image of promotion as a "right" not an "award" is something fundamental that needs to be addressed, because promotion is very much relevant to the various activities and interests of a Civil Servant, both his status as an officer as well as part of society or the public. A Promotion Decree, for some Civil Servants may have no effect, but for others it carries a very important meaning, such as increase in salary / income, increase in position, increase in "status" or "prestige", and others so that to get a Promotion Decree sometimes there are some Civil Servants doing or considering legitimate any way in order to obtain a Promotion Decree that desired, such as paying some money (bribes) and so on.

Seeing the great authority of the Regional Government in the field of staffing, in terms of the promotion, the Regional Staffing Agency of Murung Raya Regency should try as much as possible to provide performance in carrying out duties as a service provider in the field of staffing such as staffing information services, promotion administration and employee requests related to services for the promotion. But it turns out that there is still news of complaints of civil servants in Murung Raya regarding the promotion of employees as stated by a teacher named Logia Markus teacher of SMKN-1 KAMPURI District Mihing Raya, who said;

"That in the process of promotion there is still no certainty of time and sometimes we feel late in the issuance of the Decree of promotion, both for the period of April and the October period, should be 1 (one) month before the TMT promotion, the Promotion Decree has been received" (interview, June 12nd 2018)

Such complaints should be reasonable, because the performance demands of a public organization are now very large, and it is imperative for every public organization including BKD Murung Raya to provide the promotion service with maximum performance in accordance with applicable regulations. However, not necessarily also the performance of delays in promotion management services is caused by the weak performance of BKD organizations, but it can also be caused by not all civil servants also understand more about the completeness of administration and processes that must be done by BKD in providing promotion services, so that in terms of service time becomes problematic, as conveyed by Trinova Handayani Kasubag Staffing and Finance BKD Murung Raya Regency. In the initial survey of researchers in October 2018, that:

“.... In the process of proposing a promotion, especially structural promotion, not all civil servants understand the procedure of promotion, for example there are incomplete files that enter BKD Murung Raya, or files that enter late processed in BKN Regional VIII (in Banjarbaru City of South Kalimantan) due to the lack of conscientiousness of officers who receive the proposed ascension file, that still incomplete civil servant files are managed" (interview, October 15th, 2018)

International Journal of Research in Vocational Studies, Vol. 1, No. 3, December 2021: 68 - 77 
The above problems can occur, for that it is necessary to deepen knowledge through research on the performance of BKD services of Murung Raya Regency. On the basis of this, the author is interested in deepening the study of performance by raising the surface of the problem with the title: "The Performance of Regional Staffing Agency Services in the Framework of Promotion of Civil Servants in Murung Raya Regency. Based on the explanation on the background of the problem and the focus of the above research, the formulation of the problems that will be discussed in this study is 1) How is the performance of the Service of the Regional Staffing Agency in the framework of promotion and 2) What factors affect the service performance of the Regional Staffing Agency in the framework of the promotion of Civil Servants in Murung Raya Regency?

\section{RESEARCH METHOD}

The approach taken in this study is a qualitative approach. It is argued that the skinative method is a research procedure that produces descriptive data in the form of written or spoken words from people and observed behavior [23]. According to them this approach is directed at the background and individuals holistically or whole. Furthermore, in general, this study aims to analyze and describe the service of promotion of civil servants provided by the Regional Staffing Agency in the Sub Field of Mutation of Dismissal and Retirement to Civil Servants of Murung Raya Regency [16].

In this study, researchers tried to display the opinions of leaders, staff and service users (REGIONAL CIVILS) in an effort to find out about the performance of civil servant promotion services provided by the Regional Staffing Agency and the regional civil servants of Murung Raya Regency in their implementation and what obstacles were faced. In the process of data collection, researchers as a key instrument that directly plunge into the field, using observation techniques, interviews, and documenters. Data analysis in qualitative research, basically done at the beginning of research activities until the end of research activities. In this study the data obtained will be analyzed using activity flows such as: Data reduction, data display and verification. In interactive model analysis, data collection activities, data reduction, presentation and withdrawal of conclusions/verification are cyclical and interactive processes. In this sense, qualitative data analysis is an ongoing, repetitive and continuous effort.

Data collected from basil observations, interviews and documentation about the performance of civil servant promotion services provided by the Regional Staffing Agency in the Sub Field of Mutation and Pension to Civil Servants Murung Raya so much and, complex and mixed, reduced to then choose which is feasible and appropriate to be presented. The process of data selection that leads to problem solving, discovery and meaning. Data is presented systematically, in order to more easily understand the interaction between its parts in a whole context, thus giving the possibility of conclusion withdrawal and verification. Broadly speaking, the data analysis conducted in this study was carried out with steps, namely 1) To record observations, interviews, and documentation and reflective notes. Then separate data that is important for research purposes from less important, 2) describes data that has been classified for further study, with attention to the purpose of the study, 3 ) examines the inscription and compares with the theory that the researcher refers to, including revising the theory, and 4) makes the final analysis and explains it in the research report [25][26][27].

\section{RESULTS AND DISCUSSION}

\subsection{Service Productivity Promotion of BKD Murung Raya}

The performance of BKD Murung Raya cannot only be seen from the internal measures developed by BKD Murung Raya such as achieving the target of increasing the rank of civil servants in the region. Performance should be judged by external measures, such as values, norms, that apply in society. A BKD Murung Raya activity has high productivity if the activity is considered in accordance with the values and norms that develop in society. One of the Productivity of BKD services of Murung Raya Regency is a service in the promotion process (KP) for all employees in the Murung Raya Regency Government itself. As for the Promotion stipulated in Government Regulation No. 12 of 2002 it is explained that the period of promotion of civil servants is set on April 1 st and October 1st every year.

Promotion is an award given for the work performance and service of civil servants concerned to the state. In addition, the promotion is also intended as an encouragement to civil servants to further improve their work performance and service. Promotion is an award and each new award has a value if the promotion is given appropriately and on time [5]. In addition, the power that is an award given to a Civil Servant (PNS) for work performance and service as an employee is certainly very influential to existing civil servants, where with the power they have will certainly affect career development and will also affect salary increases or income increases for the civil servants concerned. It is natural that an employee will expect full to get good service in the management of their promotion from the work unit or organization in charge and authorized to provide such services in this case is the Regional Staffing Agency (BKD) of Murung Raya Regency.

Based on data on the productivity of BKD Murung Raya services in June 2018, BKD data of Murung Raya Regency the number of civil servants in Murung Raya Regency until June 2018 amounted to 3,850

Performance of Regional Staffing Agency Services in order to Increase the Rank of Civil Servants of Murung Raya Regency of Central Kalimantan 
people. Then it was increased again with the addition received for regional CPNS admission in October 2018 as many as 90 people for the CPNS formation which consisted of 32 teachers, 18 health workers and 40 technical personnel. That is, BKD Murung Raya always serves the interests of civil servants in terms of regional staffing interests, including regarding the promotion of 3,940 civil servants.

Based on interview data, there are several things that can be discussed about determining the productivity of services achieved and focusing on the success of success (focus on result and creating value) as a whole as follows:

1. Performance results have involved all civil servants in BKD

The view of upper-level leaders, middle and lower level leaders, the results of promotion service performance has involved staff, although only a small percentage. Standard performance of promotion management carried out regularly daily, weekly, monthly in accordance with applicable laws and regulations. This is reinforced by the statement of the Employee Mutation Kabid which states that performance standards are based on existing Government Regulations Act. Service standards are needed in order to maintain the quality of $\mathrm{BKD}$ organization performance, where with the standard of organizational performance will also be related to determining and supporting the standard of service that will be provided by the organization in order to serve Costumers or customers (PNS) in the process of raising the rank of civil servants.

2. View standard results and measure performance

How to measure performance according to the alignment of pimpman, both Secretary, Head of Mutation and Head of Sub-Field of Appointment and Attachment is still limited to the accuracy and speed of completion time. A timely and precise promotion of the person is considered a good performance. In relation to public services produced by the performance of an organization shows that the community or in this case is a customer or customer and an organization has been united if the two interact with each other it will produce something that is very necessary to discuss, especially if the interaction is service from the organization to the customer because of course it will affect the customer and for the organization that performs the service itself. [16].

When looking at the concept of the performance criteria of a service as described above, in addition to these criteria intended so that service users are easy to access existing services, from the implementation of the service itself efforts to achieve service performance that absorbs the completion of all existing service users is also a form in the direction of service quality, this is of course important for BKD Murung Raya Regency as the leading sector in realizing performance. The promotion of civil servants can at least be an example for civil servants who use these services where their notabane is a public servant so that it is expected that they can apply and provide quality services also in all service functions that they have in their respective work.

In this case, the productivity of BKD services through its work units in terms of promotion becomes the determining part as well as the communicative service performance of the units in BKD. Basically, the performance of BKD Murung Raya is expected to show the achievement of the performance of a program in a certain work unit within a certain period of time. In this case, the promotion service, where performance evaluation can at least show an assessment of the success / failure of the implementation of activities in accordance with the goals and objectives of the mission and productivity and programs that have been set out in the planning in the vision.

\subsection{Quality of Service Promotion of BKD Murung Raya}

The achievement of service performance is the main target that BKD Murung Raya Regency wants to achieve as well as the service of promotion of civil servants. This can be seen from the direction of policy to encourage improvement of service quality, quality of human resources or coaching that has been established and outlined in the mission and productivity of the organization. Vision and Mission are very important to ensure the quality of service continuity of a Moody BKD, especially in implementing a performance management system. On a basis, these three components are the target of a BKD, where achievement is measured from the comparison of these components. Thus, strategic planning is used to realize the vision and mission and productivity of the BKD organization and share the resources necessary to achieve it. So, it can be said that a BKD organization

Murung Raya initially has ideals or final goals that want to be achieved in the long term called vision, then to realize the vision of the organization that has been determined, the organization formulates general efforts and performance to be done called mission and productivity, then to realize the mission and productivity, the organization makes / formulates special efforts that are considered the most effective and efficient to achieve the ideals of the organization called strategic planning

The development carried out in Murung Raya Regency is an integral part of the RPJMD of Murung Raya Regency and the Strategic Plan of all SKPD in the Murung Raya Regency Government environment, which requires a system, mechanism, implementation and control in a more integrated, synergistic, balanced between areas of government activities, while showing organizational performance, including the service affairs of civil servant promotion, both in the process of achievement and results(output)which is expected 
within the specified time period of the organization. Every organization has internal rules and programs to achieve its goals. No exception to the Regional Staffing Agency of Murung Raya Regency. The Regional Staffing Agency of Murung Raya Regency has a vision and mission and productivity inseparable from the internal and external environmental conditions and their basic positions, functions and tasks. Based on that, the vision carried out by the Regional Staffing Agency of Murung Raya Regency is "Carrying out Professional, Transparent and accountable IT-Based Staffing Services".

The objectives and objectives of the Regional Staffing Agency of Murung Raya Regency are the increasing service and awareness of BKD apparatus characterized by increased service facilities, increased employee welfare, the realization of rule of law, the improvement of good work culture, the improvement of religious quality of life and cultural resilience, and the implementation of good performing services. The Regional Staffing Agency of Murung Raya Regency has a very decisive responsibility and role in service to the community and efforts to improve the quality of the administration of local government in the field of staffing, the implementation of education and training and the development of regional apparatus resources directed to improve the quality of professional performance and capacity, devotion and loyalty, insight development and career development, promotion of civil servants in to improve the quality of public services.

When looking at the concept of the performance criteria of a service one of which is the result of services or products from services carried out, it is intended that service users are easy to access existing services, from the implementation of their own service performance efforts that absorb the completion of all existing service users are also a form in the direction of good service, this is of course important for BKD Murung Raya Regency as the leading sector in implementing service performance promotion of civil servants can at least be an example for civil servants who use these services where their notabane is a public servant so that it is expected that they can implement and provide quality services and perform well in all service functions they have in their respective work.

\subsubsection{Responsivitas}

Resposivity is needed so that decision makers and decision makers in BKD Murung Raya organizations will be more consistent in carrying out every implementation of services implemented by an organization. The achievement of service performance is the main target that BKD Murung Raya Regency wants to achieve as well as the service of promotion of civil servants. This can be seen from the direction of policy to encourage service improvement, quality of human resources or coaching that has been established and outlined in the mission and productivity of the organization.

The results of identification at the location of this study, the direction of the policy is in line with the internal services carried out by BKD Murung Raya Regency. The internal services intended here are the commitment of BKD Murung Raya Regency which considers employees very important in realizing quality external services, especially for the implementation of civil servant rank services, in addition it is done in order to create employee job satisfaction as service implementers which if employees who feel satisfied with BKD Murung Raya Regency will certainly also increase employee loyalty to BKD Murung Regency. The kingdom itself.

So far, the opportunity to obtain employee advice and input, especially related to problems in the process of civil servant promotion services carried out by BKD Murung Raya Regency is always accepted by the organization through staff meetings held by BKD Murung Raya Regency, as stated by the Head of Agency, Secretary and Head of Mutation and Employee Development that every month BKD Murung Raya regency conducts a staff meeting. In this staff meeting each staff is usually asked for an opinion and enter related to the problem in the work done to find solutions together. This staff meeting was conducted as a form of formal response of BKD Murung Raya Regency to all staff in order to improve the services provided by BKD to civil servants / customers / communities.

The efforts of BKD Murung Raya Regency in carrying out services to employees who are members of the organization can be seen through the management of BKD Murung Raya Regency so far carried out openly and flexibly, where the organization provides an opportunity for each employee to participate in organizational improvement efforts, especially in the implementation of civil servant promotion services carried out by BKD Murung Raya Regency through input and advice from employees as well. Na the results of the interview to the Secretary of BKD Murung Raya Regency, that for management in BKD Murung Raya Regency is carried out openly and flexibly this is intended to always provide the best service for employees of other work units who come to BKD, thus it is expected for employees who carry out services and external civil servants BKD can establish a good and open working relationship so that they can participate by providing input and advice. the condition of BKD Services murung Raya regency of course to improve BKD services in the future.

In this case, based on interview data there are several things that can be mentioned about responsibilities related to the performance of BKD Murung Raya promotion services, among others:

1. The strategy of anticipating changes in the strategy of the Regional Staffing Agency of Murung Raya regency in anticipation of changes that occur in the management of promotions is to adjust to the

Performance of Regional Staffing Agency Services in order to Increase the Rank of Civil Servants of Murung Raya Regency of Central Kalimantan 
change quickly, both rules, mechanisms, promotion requirements and so on. This strategy is supported by the leadership. Staff also support with the statement that in anticipation of change there is no strategy, just adjust as soon as possible changes exist.

2. How to make changes made by the Regional Staffing Agency of Murung Raya Regency in making changes to meet the satisfaction of those served in the management of lift increases is to simplify the mechanism and immediately socialize the change, among others, by replacing the data program.

3. Efforts to build the quality of the Regional Staffing Agency of Murung Raya Regency to build organizational capacity in connection with continuous service improvement, especially in the management of promotions are by working according to the rules to improve the quality of service.

4. How to create a high-performance organizational structure. According to the leadership of BKD, the way BKD Murung Raya regency creates a high organizational structure, especially in the management of promotion is to make a lean organizational structure, poor function-rich structure balanced with the development of human resources.

5. How to design the organization according to function, the Regional Staffing Agency of Murung Raya Regency designed its organization in accordance with the expected organizational function, especially in the management of promotions is to develop Human Resources and empower the function of BKD in the management of promotions. This agrees with the statement of the Head of Employee Mutation and KepaJa Sub-Field of Appointment and Association which "states to develop human resources in

\subsubsection{Responsilitas} accordance with their respective functions /responsibilities.

The ability and skills of service implementers in an organization have an important role in realizing good service. Every employee in an organization must have abilities and skills related to the field of work carried out. Ability and skill have different meanings, but both have a close relationship to have in each employee to carry out the work according to the task at hand. The understanding of ability itself comes from the basic word able which in relation to the task / work means can (adjective / circumstances) perform the task / work so as to produce goods or services as expected. While the skill itself is the ability of an employee in carrying out tasks / work by using the available limbs and work equipment [6][26]

This division of duties is intended so that each staff who becomes a service officer knows what the main task is in providing services. In addition, this is also in order to keep the overlap of work for the realization of good and fast service. There is a good purpose in the division of duties through the delegation of authority to carry out this service, where when carrying out the service officers become more freely, because it has been directed earlier through the transfer of existing authority. This condition can certainly shorten the level of rigidity of procedures in the service process, especially in the process of service to increase the rank of civil servants in this Murung Raya Regency BKD environment. Efforts to avoid rigidity in the promotion service procedure carried out by BKD Murung Raya Regency is felt normal, and it is also an effort to motivate more useful activists in the work.

\subsubsection{Accountability}

The Regional Staffing Agency of Murung Raya Regency motivates employees to build and use all potential to achieve their goals in work and career, especially in the management of promotions is to give direction, advice and flexibility to carry out their duties as well as possible as a form of accountability of BKD Murung Raya in providing services. The Regional Staffing Agency of Murung Raya Regency has not yet conducted an evaluation of Education and Training and Employee Development in relation to the performance of individuals and organizations in the management of promotions. The Regional Staffing Agency of Murung Raya Regency always directs and appeals for the importance of using knowledge and skills in the implementation of the task of managing the promotion.

According to BKD staff, how to serve in the management of promotion by following the standards of applicable rules and with the best. This is reinforced by the statement of the Head of Employee Mutation and Development who said to serve the increase in lift according to the regulations. There, the service is done best. But this accountability effort is needed means and support for the benefit of service, including promotion for every civil servant in the scope of the Murung Raya district government. In addition to needing the support of facilities and infrastructure, proper human resources are also needed in their fields. Contribution of Education and Training to the achievement of organizational goals, meeting the needs of employees, including development, learning and career advancement, especially in the management of considerable promotions

But in this case, the Regional Staffing Agency of Murung Raya Regency has not conducted an evaluation of Education and Training and Employee Development related to the performance of individuals and organizations in the management of promotions. The Regional Staffing Agency of Murung Raya Regency always directs and appeals for the importance of using knowledge and skills in the implementation of the task of managing the promotion but has not evaluated the performance of the implementation of the promotion management. The Regional Staffing Agency of Murung Raya Regency is an SKPD that is technically operational and administratively responsible to the Regent through the Regional Secretary of Murung Raya 
Regency, where the performance activities of BKD organizations, units and employees are oriented to the Vision of Mission and productivity and programs that have been set by the region to be further adapted to the vision of BKD's mission and accountability as a driver of organizational performance.

In BKD Murung Raya organization, achievement is often appreciated in the workplace, and employees with a very high level of ambition to get positions and power in the organization, will behave and think that the best achievements are obtained by beating others. Preferably, the best achievement is obtained from the ability to motivate yourself, in order to achieve personal growth that improves the quality and competence of oneself in the workplace. Achievements obtained from beating others through unhealthy ways, will usually be something that does not bring positive benefits to the organization. Group interests are something that can make someone who is not qualified get achievements and promotion to a higher level.

In BKD Murung Raya in terms of service promotion of civil servants, competition in the workplace explicitly does not show competition as above, but implicitly unhealthy competition is exclusively (sometimes) can occur, where the competition is related to efforts to increase income (additional money) beyond income in the form of salaries and regional benefits such as official travel money, Operational activities and incentives, even sometimes there are money tips from civil servants who conduct service matters of promotion. The Regional Staffing Agency of Murung Raya Regency is an SKPD that is technically operational and administratively responsible to the Regent through the Regional Secretary of Murung Raya Regency, where the performance activities of BKD organizations, units and employees are oriented to the Vision of Mission and productivity and programs that have been set by the region to be further adapted to the vision of BKD's mission and productivity as a driver of organizational performance.

Administrative management activities of promotion for Civil Servants, before the enactment of regional autonomy are managed by the Staffing Bureau of the Regional Secretariat (not yet the Regional Staffing Agency). Based on Government Regulation number 3 of 1980, at that time the promotion managed is a promotion for:

1. Regional Civil Servants (management of promotions up to the issuance of Decrees to be the authority of the District Government

2. Central Civil Servants of the Ministry of Home Affairs (management of promotions for the District Government only up to getting a memorandum of approval for the promotion, while the authority to issue a Promotion Decree is in the Central Government / Minister of Home Affairs). Management is carried out with a "crash programme" model; This means that it is held simultaneously within a certain time (seven to ten days) in an agreed place and carried out approximately 3 (three) to 4 (four) months before a certain period of promotion. This implementation by forming a small committee consisting of employees from related agencies, including 1) Staffing Bureau of the Regional Secretariat / Murung Raya Region, 2) Jakarta State Staffing Administration Agency, 3) Staffing Bureau of the Ministry of Home Affairs, 4) Regional Office I of the State Staffing Administration Agency, 5) Regional Secretariat / Regional Level II se-Murung Raya 6) Other relevant Agencies / Agencies

During the implementation of the "crash programme", the main job of the small committee is to complete the memorandum of approval of the promotion that the proposed promotion that has received a memorandum of approval is made by the Decree of Promotion. At the time of the crash programme, the agency that proposes a promotion will conduct monitoring by coming to the place of implementation. Monitoring means monitoring the implementation, with the aim that in the event of a file deficiency or there are other problems will be immediately known and resolved at a moment's notice. This benefits the employee who proposed his promotion, because the possibility of delays in issuing his Promotion Decree is very small.

The performance of the executor seems quite professional, because with limited time in completing the promotion by crash program, forcing all teams involved, working maximum from 07.00 WIB to 03.00 WIB, with the intention that the burden of the task that must be completed will really be resolved within the specified time. In fact, the management of the promotion at that time in general can be said to be smooth, not many complaints and not many errors / requests for errors. Initially the performance of promotion services by BKD based on the implementation of Government Regulation No. 99 of 2000, the previous period of promotion a year twice (April and October) was changed to a year four times (January, April, July and October). The authority to manage the promotion at that time, that all memorandums of approval of promotion were issued by the Regional Office I of the State Staffing Agency and the authority to issue the decree of promotion was on the Regent for regional Civil Servants in the ranks of the District Government.

Both based on Government Regulation No. 99 of 2000 on Promotion of Civil Servants and by Government Regulations indning with Government Regulation number 12 Years. In 2002, the promotion served by the Regional Staffing Agency of Murung Raya Regency was a promotion for regional civil servants to have weaknesses. The basic weakness is 1). distribution of BKN services by regional (territorial territory of the island) and 2). The service is more manual). Both of these weaknesses should now be corrected.

Performance of Regional Staffing Agency Services in order to Increase the Rank of Civil Servants of Murung Raya Regency of Central Kalimantan 


\subsection{Service Constraint Factors of Promotion}

As a technical institution in staffing services BKD Murung Raya in providing staffing management services is still felt not maximally meet the expectations of employees, such as delays in the promotion process, mutation / move, and salary increases. In general, various causes are not optimal performance of government organizations, occur in various government organizations themselves and this condition will continue if it is not immediately corrected.

Improving the performance of services to the community is not an easy thing, because it is an open secret that there is a lot of public disappointment with the services provided by the government so far. The utilization program of the state apparatus does not succeed in presenting an efficient and eager display of bureaucracy serving thecommunity[13], difficulties and obstacles that are often complained about in receiving services from the apparatus in general such as 1) Procedures and procedures of service that are lacking / unclear, 2) Burdensome or often variable requirements, 3) Service is not on time and the service / settlement time is too long and 4) Service mechanisms that are It is often convoluted, overly bureaucratic and the cost of services is uncertain.

In this case, for performance constraints in the service of promotion in BKD Murung Raya based on interview data and observations there are several factors that affect among others 1) Role ambiquity, This can happen because the implementers (officers) who serve civil servants for promotion (both structural and functional) are sometimes faced with overlapping problems or unclear regulations that should be used as technical guidelines. $\mathrm{n}$ administration of services such as between Law No. 43 of 1999 on Staffing Points and Law number 05 of 2014 on State Civil Apratur. In this case, because the ASN Act has not been issued technical rules of promotion, then the promotion service still refers to technical rules, 2) Poor time job fit, Based on the flow of the promotion service process carried out by BKD Murung Raya Regency above, there are two types of service users of civil servant promotion services that have occurred, namely after the proposed promotion file is completed by the employee who will propose, The file is then brought and submitted to BKD Murung Raya Regency through the staffing section of each employee concerned and after the file is completed by civil servants who propose promotion, the civil servant can submit their files directly to BKD Murung Raya Regency, 3) Poor technology job fit,employee performance is greatly influenced by the equipment and technology theyuse, as a result, when it comes to technology and technology. Inappropriate supervisory control system, the absence of evaluation and reward systems in government agencies. The tendency of organizations to see the performance of employees through their work, where the "output control system" is often not in accordance with the purpose and service but is based on other objectives of the organization and 4) Lack of perceived control, this problemarises due to the incompetence of employees in resolving problems that arise due to authority they do not have so that they are also not trained to overcome problems that arise with Better. Lack of team work, the absence of cooperation between employees and organizational leaders that adversely affects the performance produced. Problems can also be caused by lack of employee support (Anwar Supriadi: 2004).

\section{CONCLUSION}

As the final part of the research analysis of BKD Service performance in the framework of the promotion of civil servants of Murung Raya Regency it was stated that (1) The service performance of the Regional Staffing Agency in terms of promotions seen from productivity, service quality, responsiveness, responsibilities and accountability in Murung Raya Regency was good. That is, from the receipt of files, file verification, management to BKN Regional Kalimantan to the issuance of the promotion decree is basically in accordance with the regulations, in accordance with the vision of BKD's mission and provides good satisfaction to the community of service users (PNS) of Murung Raya regency and (2) The performance of promotion services in BKD Murung Raya which becomes an obstacle / obstacle factor such as changing rules on the technical requirements of promotion, There are still some civil servants who are late to submit their files or files submitted incomplete and the distance between BKD and BKN Regional Banjarbaru so that the enactment is scheduled earlier / faster.

\section{ACKNOWLEDGEMENTS}

The author expressed his deepest gratitude to the Regional Staffing Agency in Murung Raya Regency who has provided the research site and supported this research. 


\section{REFERENCES}

[1] Ali, Faried, H., Drs., S.H., M.S., Dr., Prof., September 2011, Theory and Concepts of Administration, From Paradigmatic Thinking to Redefinition, 2nd Print, PT. Rajagrafindo Persada, Jakarta.

[2] Law No. 25 of 2009 on Public Service.

[3] Law No. 32 of 2004 which was replaced by Law No. 23 of 2014 on Local Government

[4] Law No. 43 of 1999 on Staffing Points, which was amended by Law No. 5 of 2014 on State Civil Apparatus

[5] Ali, Faried, H., Drs., S.H., M.S., Dr., Prof., and Alam, Syamsu, Andi, H., M.Si., Dr., January 2012, Government Policy Studies, First Print, PT. Refika Aditama, Bandung.

[6] LAN, 2004, Prima Service, State Administration Agency, Soetopo.

[7] Bernardin and Russel.1993. Human Resource Management, An. Experimential Approach, terjemahan. Jakarta: Pustaka Binaman Presindo

[8] Wirawan. 2009. Evaluation of Human Resource Performance.Jakarta: Salemba Four.

[9] Hasibuan, Malayu S.P. 2003.Human Resource Management.Jakarta: Bumi Aksara

[10] Mangkunegara, A.A Anwar Prabu.2005. Evaluation of Human Resource Performance.Bandung: Refika Aditama

[11] Sedarmayanti. 2007. Human Resource Management.Bandung: Refika Aditama.

[12] Rivai, Veithzal. Et al 2013. Human Resource Management for the Company.Jakarta: PT. RajaGrafindo Persada

[13] Wibowo. 2009, Performance Management, Rajawali Pers, Jakarta

[14] Amins, Achmad, H., M.M., Dr., July 2012, Local Government Performance Management, 2nd Printing, LaksBang PRESSindo, Yogyakarta.

[15] Fahmi, Irham. 2007. Performance Management Theory and Application. Bandung: Alfabeta

[16] Moeheriono, Prof. Dr. M.Si. 2011. Key Performance Indicators. Jakarta: Rajawali Pers

[17] Dharma, Surya.2011. Performance Management (Philosophy of Theory and Application), fourth print. Yogyakarta: Student Library.

[18] Dharma, Agus. 1991. Work Performance Management. Jakarta: Rajawali Pers

[19] Tjiptono, F, and Diana, A, 1998. Total Quality Management. Andi Offset, Yogyakarta.

[20] Mulyadi, 1998, Total Quality Management, Aditya Medika, Yogyakarta

[21] Simanjuntak, Payaman. 2005. Performance Management and Evaluation, first print. Jakarta: Bumi Aksara.

[22] Musanef, 2007. Staffing Management in Indonesia, Mount Agung, Jakarta

[23] Dantes, Nyoman, Dr., Prof., 2012, Research Methods, CV. Andi Offset, Yogyakarta

[24] Dwijowijoto, Riant, Nugroho. 2003. Public Policy Formulation, Implementation and Evaluation. PT. Elex Media Komputindo, Jakarta.

[25] Buckles, Vincent, 1997, Quality Management. Gramedia Pustaka Utama, Jakarta.

[26] Safroni, Ladzy, M., K.H., M.Ag., Drs., November 2012, "Public Service Management and Reform" in the context of Indonesian bureaucracy (Theory, Policy, and Implementation), First Print, Aditya Media Publishing, Malang.

[27] Suharto, Edi, Ph.D., August 2010, Public Policy Analysis (Practical Guide to Reviewing Social Issues and Policies), 5th Print, CV. Alfabeta, Bandung

\section{BIOGRAPHIES OF AUTHORS}

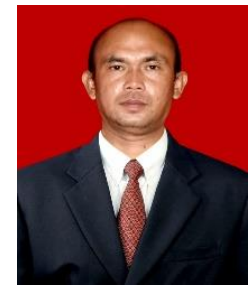

Yanson Dion, SE., M. AP. Born in Muara Teweh, January 27, 1980. Completed bachelor (S1) corporate economics, STIE estuary Teweh and continued his education in Master Program (S2) Public Administration Science Faculty of Social and Political Sciences Lambung Mangkurat University, Banjarmasin South Kalimantan. The author works as a State Civil Apartment (ASN) in the Murung Raya Regency Kesbangpol Agency. The author is domiciled in Murung Raya Regency, Prov. Central Kalimantan. The author can be contacted by email: yansonargopuro@gmail.com 